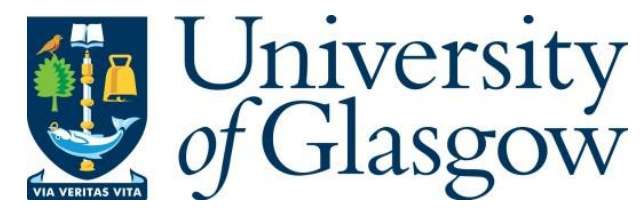

Paterson, R. (2017) Early independent production entrepreneurs in UK television: agents of a neo-liberal intervention. International Journal of Entrepreneurial Venturing.

This is the author's final accepted version.

There may be differences between this version and the published version. You are advised to consult the publisher's version if you wish to cite from it.

http://eprints.gla.ac.uk/141234/

Deposited on: 25 May 2017

Enlighten - Research publications by members of the University of Glasgow http://eprints.gla.ac.uk 


\title{
Early independent production entrepreneurs in UK television: pioneering agents of neoliberal intervention
}

\section{Richard Paterson}

British Film Institute,

21 Stephen Street, London, W1T 1LN, England, UK

Email: richard.paterson@bfi.org.uk

\begin{abstract}
This essay focuses on the operation of the UK independent television production sector in the context of the entrepreneurial aspirations of company owners in the 1990s. The calculative practices used running these small and medium sized companies are examined and the experiences in managing them are mapped as they negotiated an evolving fitness landscape. Analysis is provided of the strategies adopted including the need to develop reputation and relational contracts to secure a constant flow of commissions. Conclusions are drawn about this transitional phase of entrepreneurship in this sector ahead of government intervention in the market through imposing new terms of trade between independent production companies and broadcasters.
\end{abstract}

Keywords: independent program production; entrepreneurs; UK television; neo-liberal intervention; calculative practice; reputation; fitness landscape; UK.

\begin{abstract}
Reference to this paper should be made as follows: Paterson, R. (xxxx) 'Early independent production entrepreneurs in UK television: pioneering agents of neoliberal intervention', Int. J. Entrepreneurial Venturing, Vol. X, No. Y, pp. $x x x-x x x$.

Biographical notes: Richard Paterson is the Head of Research and Scholarship at the British Film Institute. He is also the Honorary Professor at the Centre for Cultural Policy Research, University of Glasgow.
\end{abstract}

\section{Introduction ${ }^{1}$}

The growth of the independent television production sector in the UK provides an important case study of entrepreneurial activity in creative industries. Its rapid growth from a few companies to more than a thousand fitted neatly into an ideological moment - neoliberalism - with the development of a competitive production sector in a market where the government provided regulatory framing to sustain entrepreneurship (Gane, 2012). The number of independents grew rapidly after 1981 when the legislation establishing Channel 4 signalled new entrepreneurial opportunities in program production and coincided with the end of the closed shop in TV which had given trade unions control of entry to working there. The aspirant producers - a new group of entrepreneurs - became the agents of change in this new broadcasting ecology. However, the economics of the sector lacked the drivers for scale until a series of regulatory 
interventions, first quotas of independent productions for the public service broadcasters, and then changed terms of trade in 2004, and most recently tax incentives for high end productions, accelerated profitability and led to consolidation, with the emergence of what is seen as an increasingly successful export sector.

Table 1 Key interventions 1977-2016

\begin{tabular}{|c|c|}
\hline 1977 & Annan committee recommends creation of Open Broadcasting Authority \\
\hline 1982 & Channel 4 launched as a publisher-broadcaster \\
\hline 1986 & $\begin{array}{l}\text { Peacock Committee recommends } 40 \% \text { quota of independent productions on BBC } \\
\text { and ITV }\end{array}$ \\
\hline 1987 & Voluntary independent quotas introduced on BBC and ITV \\
\hline 1988 & White paper: Broadcasting in the 90s: Competition, Choice and Quality published \\
\hline 1990 & $\begin{array}{l}\text { Broadcasting act establishes a } 25 \% \text { statutory quotas of independent productions on } \\
\text { BBC and ITV }\end{array}$ \\
\hline 1991 & ITV franchise auction \\
\hline $\begin{array}{l}1992 \text { to } \\
2004\end{array}$ & Consolidation of ITV network \\
\hline 1992 & Channel 3 networking arrangements report by Director General of Fair Trading \\
\hline 1993 & $\begin{array}{l}\text { Monopolies and mergers commission report on ITV network centre BBC Producer } \\
\text { Choice introduced }\end{array}$ \\
\hline 2002 & $\begin{array}{l}\text { ITC report chaired by Bob Phillis recommends changes to terms of trade between } \\
\text { public service broadcasters and independent production companies }\end{array}$ \\
\hline 2003 & $\begin{array}{l}\text { Communications Act mandates a code of practice on terms of trade. Ofcom } \\
\text { established as competition and content regulator }\end{array}$ \\
\hline 2004 & $\begin{array}{l}\text { Negotiated terms of trade under codes of practice come into force. } \\
\text { Merger of Carlton and Granada to form ITV plc }\end{array}$ \\
\hline 2006 & BBC introduces Window of Creative Competition (WOCC) and in-house guarantee \\
\hline 2013 & Tax incentives introduced for high-end TV productions \\
\hline 2016 & BBC announces abolition of WOCC and sets up BBC Studios \\
\hline
\end{tabular}

\section{Theoretical background and method}

The research data reported in this paper provides evidence of the practices, calculations and emerging issues for an entrepreneurial cohort in the UK independent television production sector. The data was collected between 1994 and 1998 for the BFI's television industry tracking study (BFI, 1999), in which 450 creative workers in television, completed questionnaires and diaries every four months. The data collected related principally to individual career trajectories and included 66 owners of independent production companies (Dex et al., 2000; Paterson, 2001).

The focus in this essay is on the individual agency of these owner-entrepreneurs in relation to creative firm foundations and development (Hannan and Freeman, 1989). The importance of relational contracts and reputation is described (Rousseau, 1995; Gereffi et al., 2005) and used in conjunction with the methods associated with actor network theory and the concept of the 'adaptive walks' of firms negotiating the turbulent evolving fitness landscape of their sector (Kaufmann, 1993; Padgett and Powell, 2012). 
This is framed by insights from the recent work on entrepreneurial firms and, for this industry, the tensions in the relationship of rents and opportunism (Alvarez, 2007; Williamson, 1991) within a regulatory regime which was initially established as a quasi-market to reap the supposed efficiency gains of free markets without affecting the beneficial structure of public service broadcasting (Deakin et al., 2009).

Table 2 Study participants quoted in this essay ${ }^{1}$

Male 20-13 entered TV in 1992 through a work placement then a series of freelance jobs as researcher/associate producer at multiple companies. Set up company in 1993.

Male 30-1 entered TV in 1980 as trainee at BBC. Left BBC in 1986 to set up company.

Male 30-5 was a journalist before entering TV as researcher at ITV network company in 1986. Producer at two independent companies before setting up company in 1990.

Male 30-6 entered TV as researcher at an independent producer in 1989, quickly becoming producer at range of indies. Set up company in 1995.

Male 30-17 entered TV in 1980 as a graphic designer at BBC. Set up company 1989.

Female 30-23 entered TV from public relations work. As a freelance director at a regional independent producer in 1984. Set up company in 1994.

Female 30-28 entered TV in 1978 from local radio at an ITV network company as researcher. Set up company in 1988 .

Female 30-31 worked as a corporate video producer entering TV when set up company in 1988.

Female 30-37 entered TV 1977 as a presenter on BBC. Set up company in 1989.

Male 40-1 was a radio producer before entering TV in 1975 as a researcher. Set up company in 1989.

Male 40-6 entered TV in 1972 as researcher at an ITV regional company. Subsequently Senior Producer at BBC and ITV network companies. Set up company 1987.

Male 40-7 joined BBC 1967 as general trainee. Subsequently became a producer at BBC and an ITV network company. Set up company 1992.

Male 40-10 former teacher. Set up company in 1987.

Male 40-28 entered TV from journalism in 1979 as researcher at an ITV network company. Set up company in 1987.

Male 40-29 a photographer, entered TV in 1971 as researcher at an ITV network company, then freelance producer/director. Owner from 1990.

Male 40-32 was a former academic. Set up company in 1982.

Male 40 entered TV from advertising in 1973 at BBC as an assistant floor manager then director/producer. Set up company in 1994.

Male 40-35 entered TV from teaching in 1983 at BBC as an assistant producer. Set up company in 1989.

Male 40-38 a freelance journalist entered TV 1968 as a reporter at an ITV network company. Set up company in 1988.

Male 40 entered TV in 1968 at BBC as an assistant floor manager, subsequently freelance producer from 1979. Set up company 1992.

Notes: ${ }^{1}$ Participants were anonymised and allocated a code based on their gender and age cohort. Companies represented in the study were also anonymised and allocated a distinguishing number. 
Table 2 Study participants quoted in this essay ${ }^{1}$ (continued)

Male 40-41 entered TV in 1975 as a floor assistant, BBC. Subsequently producer BBC. Set up company 1995.

Male 40-44 worked in theatre before entering TV in 1973 at an ITV regional company. Set up company in 1981.

Male 40-49, a journalist entered TV in 1983 as reporter at an independent production company. Set up company in 1986.

Male 40-51, academic and community worker. Set up company in 1982. Leaves industry in 1997.

Female 40-6 worked in radio joining BBC in 1972 in acquisitions. Company set up 1983. Returned to staff role at BBC in 1995.

Female 40-11 worked in film industry in administration, entering TV 1975 as program coordinator at an ITV network company. Set up company 1987.

Female 40-18 entered TV 1977 at regional ITV company. Set up company in 1989.

Female 40-20 entered TV from journalism as a researcher at an ITV network company in 1979. Set up company in 1988.

Male 50-1 entered TV at BBC in 1963. Freelance director after 1966. Set up company 1994.

Male 50-17 entered TV from journalism in 1979 as a reporter at an ITV network company. Set up company in 1988 .

Male 50-21 entered TV from journalism in 1963 as a reporter at a regional ITV company. Subsequently executive roles at BBC and an ITV regional company. Founded company 1992.

Male 50-26 had various educational roles prior to entering TV in 1976 at BBC as production assistant. Subsequent roles as the director and producer at ITV companies before setting up company in 1988 .

Male 50-28 entered TV 1963 as a production trainee at an ITV network company. Variously worked in freelance and staff director/producer roles with BBC and ITV from 1969. Company set up in 1991.

Male 50-31 a photographer entered TV 1964 as freelance cameraman. Set up company in 1994/

Female 50-9 entered TV in 1965 at BBC as a reporter. Set up company in 1983.

\footnotetext{
Notes: ${ }^{1}$ Participants were anonymised and allocated a code based on their gender and age cohort. Companies represented in the study were also anonymised and allocated a distinguishing number.
}

The material context and the associated anthropology of calculative practices of independent entrepreneurs in television production in the late 1990s (Callon, 1999) are elaborated from responses to questions posed in the 12 waves of data collection between 1994 and 1998. These individuals (see Table 2) were participants in a fitness landscape for program production which was continuing to change as both the BBC and ITV altered their organisational structures and processes to accommodate the new market realities which followed the intervention establishing quotas in 1990.

The reported experiences and practices of individual entrepreneurs faced with the need to develop relational contracts in the face of uncertainty are counterposed to the emerging and rapidly changing ecology of the whole television industry. These accounts prefigured further regulatory intervention in the early 2000s with the change in the terms of trade which were secured on the perceived need to reduce buyer power of the broadcasters and provide an IP regime more favourable to the need for independent producers to create sustainable businesses (ITC, 2002; Doyle and Paterson, 2008). A 
consistent tension in the relationship of broadcasters to the independent sector, and between creative aspiration and management necessities, is perceptible in the accounts reported here as is the increasing realisation that the firms they had created could only be sustained with capital investment. It was a period of transition as a relational governance structure was solidifying and became transformative.

\section{Early history}

By the mid-1980s there was a growing recognition that there were insufficient commissions to sustain the number of production companies which had been founded at the start of Channel 4, four years earlier. The new ecology of production in television had created a new and uncertain fitness landscape and, when the Peacock Report (1986) praised the virtues of 'entrepreneurial spirit' and recommended quotas of independent productions for both the BBC and ITV, which were both then vertically integrated, government acted quickly. A regime requiring the BBC and ITV to commission $25 \%$ of programs from the independent sector was implemented in 1990 and was followed by a concerted effort by the independents' trade association to secure adequate terms of trade to enable the development of a viable third production sector (Darlow, 2004).

Many independent companies remained small in the mid-1990s and had survived within the beneficent Channel 4 regime with a cost plus regime of payments on commissions (a fixed percentage on the production budget). Some began to develop sustainable businesses when they secured returning series and the emerging governance structure for the industry was however evolving. The start-ups founded in the early $1980 \mathrm{~s}$ had initially been captive to Channel 4 but this changed as capacity and skills were built up. A commissioning relationship defined by relational governance emerged (Padgett and Powell, 2012) with increasing supplier competence and better codification of transactions.

ITV and BBC had changed as a result of the perturbation from the burgeoning independent sector. The franchise renewals in 1993 fundamentally altered the complexion of the ITV network. Instead of the pillars of five network companies providing the bulk of the schedule the appointment of a publisher-broadcaster (Carlton television) altered the situation. Carlton outsourced most production and, because it inherited the London weekday franchise, displaced the incumbent Thames Television which became a new large independent company. The BBC spent most of the 1990s adapting to the new broadcasting regime both internally with the introduction of Producer Choice, and externally in its relationship with the independent sector (Birt, 2002; Born, 2004). The displacement of personnel from both parts of the duopoly resulted in new independent company foundations in the 1990s and these changes were reflected in the data reported here.

The literature on firm foundations and mortalities (Hannan and Freeman, 1989) suggests a normative trajectory in relation to firm density while work on organisations by scholars adapting Kaufmann's population biology (Rivkin and Siggelow, 2002), have described a pattern of adaptive walks across a fitness landscape marked by degrees of ruggedness. For many of the small companies in this period making a living became progressively more difficult, while for medium sized enterprises sustaining a sufficient throughput of commissions put their business models under constant pressure. There were discontinuities in the population of firms engaged in production and a process of 
continual evolution. Nelson and Winter (1982) have suggested that equilibrium in any sector is unusual and populations of firms evolve locally (by satisficing rather than maximising globally) in the direction of higher aggregate efficiency. Hannan and Freeman (1989) noted that 'organisational types generally originate rapidly in a relatively short historical period, to grow and change slowly after that period'. Both phenomena were observable in the UK program production sector. Independent companies emerged as a numerically strong but structurally flawed industrial sector and the variable formation and origins of firms produced a diverse set of firm types. As Winter et al. (2007) note "processes [...] can be interpreted as representing the efforts of firms to find viable ways of participating in a new industry - an industry that exists only as a latent potential when the story starts".

\section{Origins}

The majority of the company founders represented in the 1994 to 1998 industry tracking study (BFI, 1999) had had experience of cultures oriented to the notion of public service and high quality programs in organisations controlled by a central bureaucracy which allocated resources (Anderson, 1990). The motivations for founding an independent production company in the 1980s and 1990s varied considerably: perceived opportunities, necessity or an attempt to secure some sort of certainty for the future (Martinelli, 1994). The level of risk was potentially very high but this was cushioned in the early years of Channel 4 by the terms of trade which provided for a cost plus formula in awarding commissions alongside what was effectively business training. This was what Winter (2000) has described as capability learning for many of the new firms founded at that time, while Deakin et al. (2009) have described this intervention as the creation of a quasi-market.

Early movers in the 1980s included people who had been trained and worked in the $\mathrm{BBC}$ or ITV. Later company foundations by ex-BBC staff ensued after the redundancies which followed the Producer Choice initiative after 1993 and this option was seen as a better alternative than freelance work or leaving the industry. The ex-BBC staff who elected to set up their own business were dominated by men from the 41-50 age cohort. Many expressed disenchantment with the large corporate bureaucracies in which they had been working and the perceived entrepreneurial opportunity occurred at the point in their working lives when previously they might have moved into senior executive or administrative positions.

The changes to the ITV franchise map created both push and pull factors in the decisions of those working in the ITV companies who left to establish their own companies. The timing of foundations was mainly defined by the fall-out from the franchise auction after the 1990 Broadcasting Act which led to redundancies as the companies adopted new business strategies. This group was also dominated by the $41-50$ age cohorts but their commercial experience in ITV gave them a greater sensitivity to business strategies and to the needs associated with running a company. The level of success of this group in creating viable enterprises were higher, and the incidence of failure less, than with the comparable ex-BBC group. So-called sweetheart deals were put in place by a number of the companies which retained their franchises encouraging producers to set up their own companies on the basis of a guaranteed commission. 
In addition, many early founders of independent production companies came from fields of activity other than broadcasting. Sixteen independent companies in the sample were founded by individuals from outside broadcasting. The new ecology provided an access route previously denied by the closed shop and oligopolistic industry structure. Many of these people had been prevented by the traditional structures from entering television and were prepared to endure the risks associated with a more open industry. The rites of passage of this group varied considerably. Some founded their companies after gaining experience in the independent sector in other roles. For example, male 40-49 who had been an investment analyst and journalist joined the independent sector as a reporter at Indie 3 between 1983 and 1986 but then co-founded Indie 42 in 1986. Male 30-6, a former journalist, became a researcher/producer at Indie 6 in 1989 and then, after freelance work at various companies, formed Indie 45 in 1995. Male 20-13, who entered in 1992 via a placement and quickly became a researcher at Indie 21, then formed his own company, Indie 44, in 1993 while continuing to work as a freelance.

One other distinct group of company founders were those already working in the industry as freelancers. Examples included male 50-1, a long time freelance producer and key member in the lobbying campaign by the trade association (PACT), who formed his own independent in 1982; and male 50-31 a freelance cameraman who co-founded Indie 46 in 1994. In describing the spur to founding a company male 40-49 claimed in March 1994, it was "the need to make a living combined with exploiting my perceived talents... we started [Indie 42] because it made sense in view of the structure of the television industry".

A range of other motivations for these start-up businesses was registered. Female 30-23 asserted that the "lack of employment structure has made this career a hard choice in many ways - though independence and earning capacity compensate to some extent". Male 40-28 noted, "I have gravitated towards independent production because I like working in small institutions. It gives me creative freedom". The notion of entrepreneurial independence underpinned the decision by female 40-20 to "set up an independent production company to enjoy more freedom and a wider variety of programme-making opportunities"; while male 30-1 wanted 'to establish one's independence - both from the tyranny of a huge department that told you what to work on rather than allowed you freedom of choice; to establish a track record strong enough for people to be able to back me and the company with confidence'.

\section{Factoring the entrepreneurial: the material context of ownership}

Learning about management and the perils of being an entrepreneur were described in the responses to questionnaires. Many were dismayed by the impact on their businesses of an open market in the supply of programs and the lack of any guarantee of commissions. Hannan and Freeman (1989) have noted there is a "relationship between waves of prior entries and the exit rate. One way to view this is that when entry rates are high, a larger number of firms enter the industry with fatal flaws in their design, in business strategy, or in managerial expertise". Furthermore, Alvarez (2007) points out lack of managerial expertise is why entrepreneurs who specialise in early stage firm governance must often be replaced by professional managers if the uncertainty facing a firm changes into risk. 
The uncertainties that came with running a company were sometimes expressed quite starkly: male 40-32 (March 1994): "small independents are doomed. Profit margins no longer exist". Male 40-1 (March 1994): "now run my small but growing independent production company as opposed to being on relatively secure well-paid contracts - now the risk is huge and there is small chance of better gain than in contract position. Overall much more stressful". A stocktaking of the opportunities for securing commissions was a regular feature of the independent owner's life as the realities of running and sustaining a business rather than creative fulfilment became the priority. Female 40-11 in November 1995 commented "according to PACT their year book changes by a staggering $30 \%$ each edition, so $30 \%$ of the companies disappear and are replaced by $30 \%$ of new hopefuls but the market is still overcrowded". And then, in May 1997, she commented "I really do doubt whether there is a future for small companies like [Indie 29] - unless we're prepared to do it 'as a vocation' and earn very little money and live with the constant insecurity". Another small indie owner, female 50-9, commented in March 1994 "at present the profit margin in independent production is too low to run a viable business".

Female 40-6 observed in March 1994 "I left the BBC because I wanted to widen my opportunities and make programmes of my own choice. Now it is a case of both keeping working therefore doing what is available, and continuous pitching”. Then in May 1995 she conceded;

"I have finally faced the fact that the work I am doing with a small independent company is essentially, ultimately not viable unless we change the range of work, and I don't want to do that. I have been looking at the reality of the scenario for some time; knowing that the overheads were a burden and feeling trapped from pursuing a more individual direction [...] It has become clear to me that we must stop now before we incur any further liabilities."

As Callon (2007) notes calculative practice is integral to running an enterprise and encompasses material elements and discourses as well as competencies and embodied skills. What perplexed many was the distracting nature of some of the work they had to undertake which lay outside their earlier experience and for which they were ill prepared. This was particularly marked for the 40-50 age cohorts. For example, male 40-28 noted in March 1994 "have been forced to come to terms with a range of skills: financial accounting; business affairs (contracts and negotiations), copyright, etc. that I would never have needed to know. This has been double-edged: positively, it has presented me with new challenges. Negatively, it has eaten into time I might have devoted to programme making". Similarly, male 50-28 (March 1994) "I now have an entrepreneurial role which is quite new to me - nothing at the BBC really prepared me for this even though I was responsible for major series". However, in contrast, male 40-41 (November 1995) was "looking forward to taking more control of my professional life".

\section{Strategies}

As firms negotiated their place in the evolving ecology of the sector different challenges testing entrepreneurial resolve arose. Response to turbulence (Siggelow and Rivkin, 2005) and the necessity to adapt to survive led to particular strategies for medium-sized independent companies which had both irreducible overheads and insufficient capitalisation. These firms were very dependent on maintaining a constant stream of commissions to cover basic costs let alone being able to invest the additional capital 
required for growth of the business. The fitness landscape was overwhelmingly tilted in favour of the incumbent vertically integrated broadcasters even though their operations were under increasing pressure from external forces too (the growth of a satellite channel ecology, technological change, regulatory changes).

As new suppliers entered the market there were increasing demands on the independent production companies. There were variable levels of success and a high mortality rate. The Price Waterhouse survey in 1995 showed that profitability (in percentage terms against gross turnover) varied dramatically across independent producers with some of the smaller companies $(61 \%$ of the sample with an average annual turnover of $£ 257,000)$ achieving better results percentage wise than their larger competitors $(19 \%$ of companies with turnovers ranging from $£ 1.5$ million to $£ 16.3$ million). Interestingly, medium sized production companies in the survey reported more non-recoverable development projects than the large production companies possibly because they needed to secure more commissions in order to grow and achieve stability. Another factor was that some large independents (focused, for example, on sport) operated in specialist niches requiring less speculative development.

The much smaller companies faced other problems but often were able to continue to exist as they had very low overheads and were run by individuals who sometimes freelanced as well. In the mid-1990s Channel 4 continued to be the principal source of commissions for 500 companies and many of the smaller firms remained in a captive mode of governance (Padgett and Powell, 2012). Male 50-2 commented in November 1996 "we are trying to expand at a time when the competition gets harder by the day. But size is more important than 5 years ago"; and then added in May 1998 "the pressure on budgets at the negotiation stage and during productions consumes more time and creates more pressure on production".

Cost cutting was one consequence in small firms competing on slim margins for commissions. Male 40-7 commented in November 1996 "I see the exploitation of young people all around me, many working for nothing, many good experienced producers out of work for months, women without pregnancy leave, etc.”. Female 40-8 remarked (May 1997), "I'm subsidising the production: what is going on in this industry? My budgets for this series are $20 \%$ less than for a similar series 7 years ago, and with a smaller production fee [...] Small independents want to stay autonomous but the idea of a year without work or having to jobbing direct is frightening!!”. In similar vein, male 40-1 wrote in November 1996 "the company is still running project to project. Any serious gap would be a disaster and probably shut us down. We could do with more regular work instead of one by one commissions".

There were conflicting and sometimes unrealistic business strategies in operation as companies negotiated the fitness landscape seeking to establish a beneficial foothold. Owners had to be calculating agents, knowing and pursuing their own interests in order to take informed decisions (Callon, 1999). Some explained the inherent tension they experienced between the creative endeavour and fulfilment and the business of running a company. Male 40-39, a drama producer, suggested in November 1994 that "the most frustrating aspect of running an independent production company is the impossibility to long-term plan. It is unfair on the business, the creative team, and all those individuals we depend on to "deliver the goods"'. In November 1996 he added "we have survived well considering the impossibility of properly and efficiently running a business in tandem with creative thinking and planning. But it's still enormously unpredictable". 
The reactions of the company owners to their role and their calculation of what might be an appropriate strategy in the fast changing environment varied. Male 30-17 (November 1995) "the main stress of being a company director is reconciling the need to make money - to stay in existence - and the personal and creative aspirations of employees". Female 30-31 (March 1994)

"We were enticed/encouraged to begin our own independent production company in 1988 because of the changes in the industry and naturally, running a small company meant we had to take on more of all of those (creative, technical, organizational, managerial, financial changes) and could not afford to take on people who were not multi-skilled or willing to be trained to be multi-skilled."

Male 40-44 (May 1998) sought security for himself and his company:

"I would like to provide myself and the company with more forward security. We want to keep enough volume work (i.e., big series) to guarantee security of employment to our large staff, and allow us the possibility of doing one or two more ambitious projects, such as an upmarket special or a movie."

A reluctance to transform his approach in order to conform to market demands perplexed male 40-7 (November 1996).

"I have failed to make my company more responsive to the needs of the market; mainly because I don't want to do what the market wants. Why bother to make a film about Errol Flynn which had nothing to say? Now this may be pure arrogance and demonstrates I'm getting out of touch. I don't know how long I can go on. I'm in danger of becoming a rather bitter, boring old fart."

And he showed extreme caution in making longer term commitments so that in May 1998 he recorded that:

"We are squatting in the basement of a building off the Pentonville Road while the top floor is redecorated for us [...] we were in Camden Town but the lease ended. The company wanted a 10 year unbreakable lease at a much higher rate. I couldn't commit for 10 years. I don't know what size of business I'll have in 10 years."

Individual entrepreneurs were aware of the problematic state of the sector. Male 50-21 commented (May 1998):

"In my view the assumption that an independent company can be run from a front room out of a cardboard box is a recipe for disaster. Core teams must be retained; that is what production fees are for. They should not be confused with 'profit'. This has become a major and possibly terminal issue within." [Indie 32]

The wider context of the changing fitness landscape and signs of the transition to a relational governance mode were manifested in male 40-28's comments in November 1996:

"Increasingly [Indie 6] is unusual in being a genuine independent - owned by its principals. I'm not sure we will be in 5 years' time. We are on the edge of being a big successful company but increasingly the big companies - Pearson, Broadcast, etc. - are becoming very big and developing competitive advantages to which we must respond. I need to discover a different kind of creativity."

Earlier, in November 1994 he had commented: 
"The two prongs of our strategy are relatively low budget high volume domestic programming (such as the regional ITV shows) alongside relatively high budget low volume projects such as the international co-productions ... The success of our series [...] has boosted our reputation in the US and given us the potential of a whole new market. However it is not easy."

A strategy for growing the business was identified by male 40-1 in May 1997: a restructuring of the company was underway "to ensure:

a our survival since I do not believe the small to medium size indie has a future greater than the kitchen table unless we get bigger and attract serious finance

b we have more good ideas than we can handle at our staffing level and we need to have teams working on productions with my own contribution being increasingly that of executive producer".

This positive outlook is put into context by the experiences of Male 40-6. A producer who had worked in both the BBC and ITV, in March 1994 he was running 'a medium sized business (turnover $£ 5.6$ million in 1993). I have had to learn management. We are funded by $3 i$ the venture capitalists and another major stakeholder'. In November 1996 he worried 'that because of the financial commitment I have made that I could lose my house if we do not break through in 1997. But over the last two years we have been focused and well run and we've stuck to our business plan'. By May 1998 his company is in deep trouble and is seeking "to become part of a larger independent group, either through being taken over or through merger". By 2001 the company was in liquidation.

\section{Relational contracting and reputation}

Central to program production is the tacit knowledge exchanged between the buyers and the sellers (Gereffi et al., 2005). By the late 1990s it was accepted that the independent production companies could be highly competent suppliers so there was increasing motivation for broadcasters to outsource to gain access to their complementary competencies. The mutual dependence that emerged was largely managed through reputation, often backed up by social and spatial proximity. Commissioning editors preferred to deal with known entities.

As Caves (2001) observed 'many complex creative deals occur in communities that are very efficient at maintaining and adjusting reputations for contract fealty'. Furthermore, television programs are a non-standard product which puts an emphasis on the relational aspects in the commissioning process. Television production has a high degree of asset specificity motivating complex firm-to-firm relationships. Network theorists argue that trust, reputation, and mutual dependence dampen opportunistic behaviour, and in so doing make possible more complex inter-firm divisions of labour and interdependence than would be predicted by transactions cost theory (Powell, 1990). Owners in this study were very aware of the importance of ensuring a good reputation for their companies with the commissioning editors. Male 20-13 confirmed (March 1994) that "the management of the independent sector is obviously becoming more business orientated. It seems to depend on single strong and eccentric characters at the head of independent companies. It also depends on their personal/professional relationships with commissioning editors". 
In addition to the maintenance of the reputation of a company there was a need for owners both to achieve a sufficient size by building both a unique set of competences and a credible profile. However the high levels of asset specificity led to some opportunism and increasing differences over value (Williamson, 1983). Male 40-49 noted (March 1994), "there will be continuing demand for original programming; there will be pressure on price; there will be increased competition. The important task is to establish competitive advantage and achieve a size of company which is economically viable", and for male 40-34 (March 1994) it was "about getting a reputation to allow some freedom and bargaining power", adding in May 1998, "it may be luckier for me in that I do have quite a good reputation and that it is fairly easy picking up work". The increasing commerciality of the transactions led female 30-37 to complain (November 1996) "commissioning departments are far more ruthless now and keeping them 'sweet' is a large part of my work" while male 30-1 remarked in November 1996, "the last year has shattered any clinging hope I had that this was a nice industry in which to work. The growth in the commissioning editors' status as powerful barons has been enormous [...] We are dependent beings pawning ideas to those who have the largesse to give us work".

\section{Calculations and relationships}

Each company owner of an independent production company had to maintain knowledge of commissioning needs and continuing access to commissioning editors. Good relationships with broadcasters were crucial to unlocking the majority of the financial resources for production available to an independent production company. Developing program ideas and commissioning was a shared calculation both inside a broadcaster and in an independent producer albeit based on an unequal power relationship between commissioner and producer (Preston, 2003).

With a variety of timetables for the commissioning process across the broadcasters, the independent companies had to make adequate preparations and undertake timely initial development work, often at their own cost. Male 40-35 observed in November 1996 'as an independent producer [...] I can't complain about the amount of work I've had in the past few years, but the future is never secure, and there is the constant need to chase work, and try to do more work than is comfortable, to lay in money and possibilities for the future" so that in May 1997 his company were "just about recovering from BBC and Channel 4 schools commissioning rounds. They are [Indie 72's] principal customers, and we put a lot of work into a total of eight proposals [...] I think the next couple of years will be leaner than the last two".

Every firm's calculations required access to buyers (the broadcasters). Different degrees of openness were experienced across the channels. Male 40-10 noted in March 1994 "I have totally failed to breach the ITV network. Still plod backwards and forwards between $\mathrm{Ch} 4$ and $\mathrm{BBC}$. In the BBC increased referral upwards (and shit flowing downwards) it puts almost total control in hands of controllers". This perspective was confirmed in May 1998 by the comments of male 20-13 who was then working as a consultant with $\mathrm{C} 4$ education and commented that "the whole process has taught me that being a small independent is next to impossible. The time $\mathrm{C} 4$ takes to make its mind up is just too long to sustain. They are paralysed by indecision and ignorance of how the independent sector works. Either that or they don't care". 
A degree of hard-headed realism entered most calculations of relationships of owner-entrepreneurs with broadcasters. Male 30-5 averred in May 1996 "cynical though it sounds, in the end, more commissions come to an independent through relationships with commissioning editors than anything else". The frustrations with the process were encapsulated by male 40-10 in November 1995:

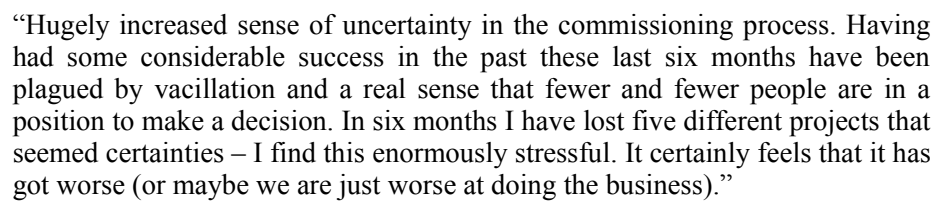

There was variable evidence of the assessment of risk or success criteria in terms of ratio of submissions to commissions in the calculative practices within an independent producer's overlapping social worlds (Law and Urry, 2004). Male 40-38 confessed in November 1996, "continue the endless task of dreaming up and writing programme proposals. I try to send off one a week [...] continue I must: we need at least 2 more hours of premium programming before the end of the financial year to keep the Bank manager happy". He also commented "it's harder to get commissions [...] too many people chasing too few commissions". Male 50-26 observed in March 1994 "frustration over commissioning process. Have had to change workload. Spend much more time developing proposals, most of which are never commissioned", and then in May 1995 claimed " $90 \%$ of time spent developing projects, networking, pitching, etc. This is not the basis for a sound industry".

In May 1996 female 30-28 remarked "the experience that I have in the business has taught me to be patient and focused on the schedule. It is a complete waste of time developing ideas for slots that do not exist". The view of male 40-49 in May 1996 was that "the most successful approach is: know what the customer wants. This is a combination of using contacts, making approaches, pitching, responding to approaches from broadcasters".

\section{$9 \quad$ Negotiating talent and uncertainty}

The material context of independent producers in the late 1990s was marked by rapid change. Freelance employment had grown significantly with the change in the structure of the industry in the 1980s (Ursell, 1998; Paterson, 2001). As employers, the owners of companies regularly discussed the importance of retaining talent in their responses to the questionnaires. In November 1996, male 30-1, reflecting the precarious state of the program making sector, noted that:

"The ability to try and keep talent on a staff basis is being undermined in the broadcast sector as greater and greater concentration takes hold. The increasing pressure to hire and fire per film rather than provide continuous employment (and therefore better skilled staff, as expertise and experience is often lost or dissipated) has put greater financial demands on middle-sized companies. Currently we do not make enough money as a business from our broadcast projects in order to sustain development and growth. Since broadcasters understandably do not want to commit to companies - rather to projects planning is becoming extremely difficult." 
Eighteen months later things had turned worse so that he wrote:

\begin{abstract}
"Planning a business has become a nightmare [...] by June we will be smaller down to a staff of three. Everyone else will be on contract $[\ldots]$ I see the growing number of mergers will increase (It is so hard being middle sized - so greater consolidation will inevitably take place). Inevitably this will have an impact on the freelance market - at both production and craft grades. The skilled freelancers will be in demand - great demand - and their rates will continue to rise."
\end{abstract}

Building a loyal staff was seen by many as a central objective suggesting an intuitive understanding of the importance of the relational contract in achieving successful projects or building a firm (Rousseau, 1995). Most independent owners, whether running small or medium sized companies, favoured at least some continuity of personnel through the use of teams of known and trusted workers. There was a consistent validation of working with those you know. Male 40-34 "I work with a lot of same people. It suits my temperament. I like working with people that I respect and like and who feel the same for me". Male 50-28 "I have worked with the same group over past year - it's a team ( 8 or 10) that I know well, their strong points as well as their weaknesses. It's vital to successfully running a small company".

Financial resources were seldom available to continue to employ people, no matter how valuable they might be, on future projects yet to be commissioned. So, for example, Male 50-17 in March 1994 stated his preference for a regular team but added "turnover is a nuisance; it reduces the collective creativity of the company. But we do what we can to hold staff'. Similarly, Female 40-11 noted:

"We have a core of 'tried and trusted' colleagues who work with us intermittently depending on their availability/our needs. The benefits are great when a 'team' is already familiar with each other's foibles. However, I do make an effort, during the 'quiet times' to get to know more/new people. I generally have at least 1 or 2 - or more - new people on each project alongside the 'old stalwarts'."

At Indie 6, Male 40-28 addressed the problem of retention in November 1994:

"Hanging on to talented staff is the most difficult thing for an independent producer. By and large we don't have the resources to contract people over a long period. Yet attracting good projects and delivering them is precisely about hanging on to talent. We can't offer long-term contracts and - while we pay the rate for the job - we can't attract people through significantly higher salaries. So we have to offer other things - a congenial place to work and, most importantly, the chance to work for a company which takes quality seriously."

What was at stake here was both the relational contracts and the opportunities which accompany the accumulation of social capital (Burt, 1997). The absence of these relationships could be a fundamental weakness for any small company which was as a result unable to build the trust and retain staff because of a lack of resources. 


\title{
10 Obstacles to growth
}

The increasingly market-led agenda in the broadcasting economy had led to the recognition of the need for firms to access finance and to engage with the issue of asset ownership directly as they struggled to build sustainable businesses. The 1995 Price Waterhouse report had found the sector highly volatile with a very patchy record of inward investment from the city.

At the time of this research some company owners had begun to explore strategies for sustainability. A common thread was the need to retain rights in programs they had produced and to attract investment. Male 40-28, described his approach in November 1996: "we're pursuing a strategy of growth and diversity. There are more opportunities to retain rights but budgets are being squeezed and new opportunities e.g., C5, are going to a small number of companies". Male 40-29's approach had similar elements but he was also aiming to transform his firm's ownership status (November 1994):

"The company is doing quite well but I feel that it needs to be doing more work
in order to expand enough, or diversify enough, to create enough profits to
enable me to carry an adequate staff and develop enough projects that we can
keep the copyright of all in order to create our own library of long shelf life,
internationally best-selling, popular programming."

His strategy prefigured that adopted by many medium sized companies after 2004:

\begin{abstract}
"To make the company profitable and to grow it in size (primarily by upping the turnaround and value of work) [...] I've been keen to get positioned with a bigger independent production or distribution company - by being taken over. Having explored a takeover by SONY in 1993, and also with Broadcast Communications, I have settled on being taken over by a European company."
\end{abstract}

Following this take over by May 1996 he was being "encouraged to expand by acquisition. We are consequently looking to buy some UK production companies in the areas of non-fiction, drama, LE, magazines [...] The cash will come from our major shareholders". This account of an adaptive walk was to become normative ten years later as consolidation became widespread.

In contrast, male 40-28 who had set up his own company in 1987 commented in March 1994:

\begin{abstract}
"I've turned down several opportunities in the last 10 years choosing to stay an independent. I also think [Indie 6] exists on a difficult cusp. Too big to be a small independent. Too small (and undercapitalized) to be really big. But if we were to seek external funding (we currently have none) would we lose our independence? The truth is I'm motivated by making programmes and [Indie 6] is the best means to that end I've ever discovered."
\end{abstract}

In the late 1990s measures to transform the sector from a series of start-ups to a set of sustainable businesses was becoming a major issue. The balancing of the creative freedom sought by many in the 1980 s, at the foundation of Channel 4, with the realities of running a business had seen many casualties. The surviving owners of independent production companies and later entrants still faced many obstacles in attracting investment although some consolidation in the sector had started. The conditions were set for a critical intervention by the regulator and government to secure the future of the sector. 
Presaging the arguments made by the independent producers to the ITC in 2001 when seeking changes in the terms of trade, male 50-28 suggested in May 1998:

"The independent sector must develop into proper businesses - with a greater
share of the available profits in television to reinvest in programme
development and training. Currently, independents carry too much risk for the
benefits which they (might) enjoy. This is especially important now that the
independents contribute so much to the overall creativity of British television."

Furthermore stressing the future importance of international markets and breaking into high cost drama male 40-28 reported (November 1996): "[Indie 6] has broadened its base outside the UK and begun to make inroads into drama".

\section{Conclusions: the evolution of the sector}

This essay has focused on the experiences of independent production company owners over a short period, 1994 to 1998. These pioneering entrepreneurs were contending with an evolving fitness landscape of the sector with major changes underway at the BBC and ITV. In the late 1990s the surviving independent producers were beginning to marshal the arguments for government intervention in the market which would enable them to move from continued dependency on the duopoly broadcasters. In short, they sought ownership of the intellectual property rights in their programs (albeit they had been funded by the broadcasters) to build their asset-base and thus become attractive to investors.

These issues had not been foreseen by those who seized the entrepreneurial opportunities accompanying the foundation of Channel 4 in 1982. The entrepreneurs who had managed to survive the initial period had secured advantage by variously building their reputation and adapting their company practices to the competitive pressures of the market. When their trade organisation, PACT, began to lobby for legislative change in the late 1990s they invoked competition law and claimed unfair practices by the broadcasters. In 2002 a report was commissioned by the ITC which recommended fundamental changes to the terms of trade, so that producers retained the secondary exploitation rights in commissioned programs after the first transmissions (ITC, 2002). This intervention deliberately rebalanced the relationship between program buyers (the broadcasters) and the sellers (the independent production companies), leading to investment in the sector.

This intervention altered the material context of the organisational and institutional locus of the independent sector so that the calculative practices of entrepreneurship were changed and better aligned with the interests of potential investors. Entrepreneurialism in the 'independent' sector was now inflected by corporate restructuring and the incorporation of venture capital as overseas investment came to the fore. The additional impact of continuing technological change and the rapid development of a global market in programming was followed by the changed role of most of the successful pioneering founder-entrepreneurs as their companies were acquired and consolidated into larger companies (Oliver and Ohlbaum Ltd., 2011).

The UK 'independent' production sector is now dominated by foreign conglomerates which were further encouraged by a set of new tax incentives for high cost program genres seen as key to export success and requiring significant investment. New start-ups continue to emerge - often connected with recognised creative talent - attracted by 
opportunism and the rent seeking associated with the asset specificity provided under the new terms of trade. Many of these companies have a greater clarity of strategy than had been the case for most production companies set up in the 1980s and 1990s and some have significant minority stakes held by broadcasters or the large consolidated independents.

The early emphasis on creative freedom in independent production has now been replaced by a singular emphasis on the sector contributing to economic growth in line with government policy. Independent television production provides an exemplar of what has been seen as successful regulatory intervention (The Economist, 2011) and fits the current policy rhetoric on the contribution of the creative industries to GDP. However, despite a continuing emphasis on the importance of SMEs in the sector, the market discourses from the 1980s have been replaced by well-established approaches in other industrial sectors with both consolidation and investment and ownership transferred to foreign capital.

\section{Acknowledgements}

This research benefited from a major grant from the Economic and Social Research Council (Contract R000237131). This work will be further developed in 'television production in transition: independence, scale and sustainability' funded by the Economic and Social Research Council (ES/NO15258/1) at the University of Glasgow. The author wishes to thank the assessors for their constructive remarks and comments.

\section{References}

Alvarez, S.A. (2007) 'Entrepreneurial rents and the theory of the firm', Journal of Business Venturing, Vol. 22, No. 3, p.427.

Anderson, K. (1990) 'The management and organization of BBC television's programme-making process', in Paterson, R. (Ed.): Organising for Change, BFI, London.

BFI (1999) Television Industry Tracking Study: Third Report, BFI, London [online] http://old.bfi.org.uk/education/research/academic/pdf/interim3.pdf (accessed 14 September 2016).

Birt, J. (2002) The Harder Path, Little, Brown, London.

Born, G. (2004) Uncertain Vision: Birt, Dyke and the Reinvention of the BBC, Secker \& Warburg, London.

Burt, R. (1997) 'The contingent value of social capital', Administrative Science Quarterly, Vol. 42, No. 2, pp.339-365.

Callon, M. (1999) 'Actor network theory - the market test', in Law, J. and Hassard, J. (Eds.): Actor Network Theory and After, Blackwell, Oxford.

Callon, M. (2007) 'An essay on the growing contribution of economic markets to the proliferation of the social', Theory, Culture \& Society, Vol. 24, Nos. 7/8, pp.139-163.

Caves, R. (2000) Creative Industries: Contracts Between Art and Commerce, Harvard University Press, Cambridge.

Darlow, M. (2004) Independents Struggle: The Programme Makers who took on the TV Establishment, Quartet Books, London. 
Deakin, S., Lourenço, A. and Pratten, S. (2009) 'No 'third way' for economic organization? Networks and quasi-markets in broadcasting', Industrial and Corporate Change, Vol. 18, No. 1, pp.51-75.

Dex, S., Willis, J. and Paterson, R. (2000) 'Workers strategies in uncertain labour markets: analysis of the effects of casualisation in the television industry', Work, Employment and Society, Vol. 14, No. 2, pp.283-305.

Doyle, G. and Paterson, R. (2008) 'Public policy and independent television production in the UK', Journal of Media Business Studies, Vol. 5, No. 3, pp.15-31.

Gane, M. (2012) 'The governmentalities of neo-liberalism: panopticism, post-panopticism and beyond", The Sociological Review, Vol. 60, No. 4, pp.611-634.

Gereffi, G., Humphrey, J. and Sturgeon, T. (2005) 'The governance of global value chains', Review of International Political Economy, Vol. 12, No. 1, pp.78-104.

Hannan, M. and Freeman, J. (1989) Organisational Ecology, Harvard University Press, Cambridge, Mass.

Independent Television Commission (ITC) (2002) Review of the UK Programme Supply Market, ITC, London.

Kaufmann, S. (1993) The Origins of Order, Oxford University Press, Oxford.

Latour, B. (2005) Reassembling the Social: An Introduction to Actor-Network-Theory, Oxford University Press, Oxford.

Law, J. and Urry, J. (2004) 'Enacting the social', Economy and Society, Vol. 33, No. 3.

Martinelli, A. (1994) 'Entrepreneurship and management', in Smelser, N. and Swedberg, R. (Eds.): The Handbook of Economic Sociology, Princeton University Press, Princeton.

Nelson, R. and Winter, S. (1982) An Evolutionary Theory of Economic Change, Harvard University Press, Cambridge, Mass.

Oliver and Ohlbaum Ltd. (2011) The Role of Terms of Trade in the Development of the UK Independent Production Sector, PACT, London.

Padgett, J. and Powell, W. (2012) The Emergence of Organisations and Markets, Princeton University Press, Princeton.

Paterson, R. (2001) 'The television labour market in Britain', in Tunstall, J. (Ed.): Media Occupations and Professions, Oxford University Press, Oxford.

Peacock, A. (1986) Report of the Committee on Financing the BBC Cmnd, HMSO, London.

Powell, W. (1990) 'Neither market nor hierarchy: network forms of organisation', Research in Organisational Behaviour, Vol. 12, pp.295-336.

Preston, A. (2003) Inside the Commissioners: The Culture and Practice of Commissioning at UK Broadcasters, The Research Centre for Television and Interactivity, Glasgow.

Price Waterhouse (1995) Production 1995: The Results of the Price Waterhouse/PACT Survey of UK Independent Production Companies, PACT, London.

Rivkin, J. and Siggelow, N. (2002) 'Organizational sticking points on NK Landscapes', Complexity, Vol. 7, No. 5, pp.31-43.

Rousseau, D. (1995) Psychological Contract in Organizations: Understanding Written and Unwritten Agreements, Sage, Newbury Park.

Siggelow, N. and Rivkin, J. (2005) 'Speed and search: designing organisations for turbulence and complexity', Strategic Management Journal, March-April, Vol. 16, No. 2, pp.101-122.

The Economist (2011) Entertainers to the World, 5 November.

Ursell, G. (1998) 'Labour flexibility in the UK commercial television sector', Media, Culture, Society, January, Vol. 20, No. 1, pp.129-153.

Williamson, O. (1983) Markets and Hierarchies: Analysis and Antitrust Implications: A Study in the Economics of Internal Organization, Free Press, New York. 
Williamson, O. (1991) 'Strategizing, economising and economic organisation', Strategic Management Journal, Vol. 12, Special issue: Fundamental Research Issues in Strategy and Economics (Winter).

Winter, S. (2000) 'The satisficing principle in capability learning', Strategic Management Journal, Vol. 21, Nos. 10/11, Special issue: Fundamental Research Issues in Strategy and Economics (Winter).

Winter, S., Cattani, G. and Dursch, A. (2007) 'The value of moderate obsession: insights from a new model of organizational search', Organization Science, Vol. 18, No. 3, pp.403-419.

\section{Notes}

1 Each participant in the BFI television industry tracking study which tracked 450 creative workers in UK television between 1994 and 1998 was identified by a number within an age cohort. So, male 40-12 is 12th person logged in the 40-49 age cohort. The 97 independent production companies where these workers were employed were also assigned a unique identification. 